Journal

of Geography

Politics and Society

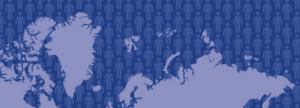

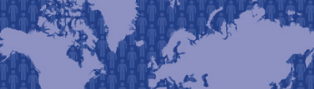

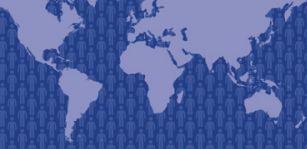

9(1)/2018

\section{Journal of Geography, Politics and Society}

$2019,9(1), 12-22$

DOI 10.26881/jpgs.2019.1.02

\title{
ETHNIC-CONFESSIONAL CYCLICALITY AND CONTINUITY IN THE PETROȘANI DEPRESSION IN THE PERIOD: 1850-2011
}

\author{
Mădălin-Sebastian Lung \\ Doctoral School of Geography, Faculty of Geography, Babeș-Bolyai University, Clinic Street 5-7, 400006 Cluj-Napoca, Romania, \\ e-mail: lungmadalin@yahoo.com
}

\section{Citation}

Lung M-S., 2019, Ethnic-confessional cyclicality and continuity in the Petroşani Depression in the period: 1850-2011, Journal of Geography, Politics and Society, 9(1), 12-22.

\begin{abstract}
The aim of the study is to comprise in one work the cyclicality and ethnic and religious continuity of the Petroşani Depression between 1850-2011. In the second half of the 19th century, the depression was subjected to cycles of colonization that had consequences for the ethnic and religious structure. The ethnic and religious continuity was preserved throughout this period, even though after 1930, some of the settlers remigrated to their birthplace. Compared to the late 19-century censuses, the herds have fallen to 2011, but none of the ethnics and confessions have completely disappeared. The statistical data used were taken from the literature mentioned during the work and on the online platform of the National Institute of Statistics. The geographic information systems were used to achieve the geographical position map at the county and national level of the Petroşani Depression.
\end{abstract}

\section{Key words}

ethnicity, confession, continuity, cyclicality, Petroșani Depression.

Published: 31 March 2019

\section{Introduction}

The space of Petroşani Depression has been subjected to colonization, due to important coal basement resources. With the second half of the 19th century, especially after the entry of the space under AustroHungarian domination, the alohton demographic contribution increased considerably. The aim of the work is to analyze the ethnic and religious structure, and to pursue the ethnic and religious continuity in the analyzed space from 1850 to 2011. In parallel with numerical developments, causes have been identified that led to the growth or decrease of religious and ethnic herds.

The territory under study comprises 7 administrative-territorial units: Petroşani, Vulcan, Lupeni, Aninoasa, Petrila, Uricani and Bănița (fig. 1). The Petroşani Depression is positioned in the Romanian Carpathian space in the south-eastern part of Hunedoara County (fig. 1).

Romanian geographic literature comprises little studies on ethnic and religious demographic structures. Several geographic studies at the beginning of the century analyzed in depth the ethnic and religious structure of some historical regions 


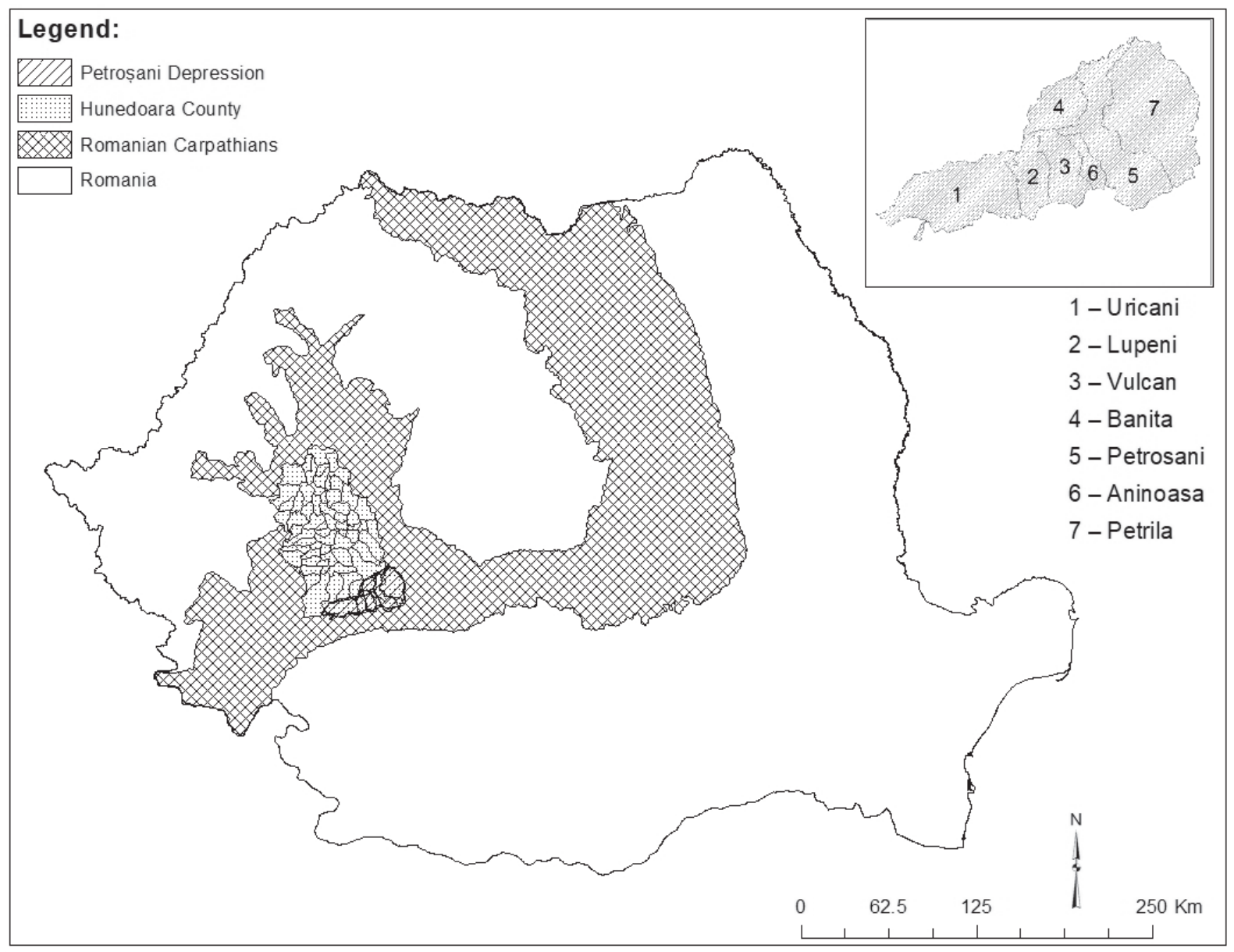

Fig. 1. Geographical position of Petroşani Depression at county and national level Source: own study.

(Transilvania, Banat, Crișana, Maramureș) for large temporal periods (Ilieş, 1998; Crețan, 1999; Bodocan, 2001; Şişeştean, 2002). These first studies analyse ethnicity and confessional together with the tendency of electoral behaviour of the population. Other research has resulted in the emergence of articles on smaller territories such as counties (Tofan, 2015, 2014; Tofan et al., 2014).

Researchers from other states, treats ethnicity and confession as causes of outbreaks of riots or even wars, a cause that can be used to destabilise a country (Rothchild, 1978; Horowitz, 1985; Levinson, 1998; Scarritt, Shaheen, 1999; Vanhanen, 1999; Reilly, 2000/2001; Fearon, David, 2003).

\section{Methodology}

A first methodological stage was the realization of a map on the administrative-territorial units that form the depression (fig. 1), respectively to geographically position the Petroşani Depression at county and national level, ArcGis version 10.3 was used to perform this map (fig. 1).
The second stage of the work focused on obtaining the statistical data needed to achieve the study.

Statistical data from censuses of 1850, 1857, $1880,1900,1930$ and 2011 were used to analyse the demographic evolution, but especially the ethnic and religious structure of the population. The data for the first five censuses were obtained following consultation of the specialized bibliography (Rotariu et al., 1996; Rotariu et al., 1997a; Rotariu et al., 1997b; Rotariu et al., 1999; Rotariu et al., 2011), and for 2011 was used the census of population and housing 2011 made available by the National Institute of Statistics. After obtaining the necessary statistical data, it has been processed, using the Microsoft Excel 2013 program. A series of graphs were made that represented the developments of ethnic and religious weights during the studied period. A table was also drawn up illustrating the demographic evolution of administrative units in the Petroşani Depression, respectively the percentages of growth or demographic decrease. The other two tables illustrate the ethnic and religious structure of the population of the year 2011. 


\section{Results and discussions}

The Petroşani Depression represents the largest and most important coal deposit in the Romanian Carpathian space. Following the settlements from the 18 th century and continuing with the 19th century, changes occurred in the geodemografice structures of the population. The operation of the extraction and coal processing industry requires a large and skilled workforce. The miners were brought in large numbers in the space of Petroşani Depression from the second half of the 19th century, when the space Carpathian Transylvanian came under dualistic occupation. As the region of Petroşani Depression was and is a great coal basin, this time both the Habsburg authorities as well as the dualistic were concerned about the statistical knowledge of demography. The focus on the censuses of the second half of the 19th century and the first part of the 20th century was due to cycles of high-importance colonization for mining evolution.

With the contribution of the new workforce, the demographic evolution of the administrative-units of the Petroşani Depression was ascended in the second decade of the 19th century. The demographic evolution of the Petroşani Depression in the period 1850-2011 is shown in tab. 1. From 1850 to 1900 , during the 50 years the population of the Petroşani region increased greatly with $297 \%$, from 7,098 people to 28,210 people. Between 1850 and 1857, the largest demographic increase was in Uricani, $155 \%$. It was followed, the Vulcan, which had an increase of $100 \%$. Bănița was ranked on the last position of demographic growth for this first temporal interval, with less than $1 \%$. At the level of all administrativeunits the increase was $40 \%$ from 1850 to 1857 . In the next 23 years, from 1857 to 1880 , the demographic evolution was constantly increasing, this time in the first position by Petroşani, with an increase in the 23 years of $159 \%$. In the second place, with an increase of $42 \%$ was Uricani, and with the lowest increase of only $13 \%$ was positioned Aninoasa. Bănița was the least populated administrative unit, being in continuous demographic decrease, starting with the 20th century and the second census of the 21st century. Referring to all six administrative units the increase was $60 \%$, in the 23 years, higher by $20 \%$ compared to the period 1850-1857. Over the next 20 years, from 1880 to the end of the 19th century, the ascending demographic continuity began in the middle of the century was maintained in highvalue rhythms. This period would be a very prolific one for Lupeni, registering a demographic increase of $333 \%$. Slight demographic decline was at Uricani, where the population has declined over the last 20 years by $22 \%$. Decrease may be placed on account of the migration of part of the labor mass to the other adjacent mining areas. In the first three decades of the 20th century, the demographics of the Petroşani Depression were continuously increasing. The disadvantages of World War I were surmounteded after the year 1918, when foreign companies holding the mining fields in the pool, made donations to the romanian authorities. The mining industry took a new momentum in the first interwar decade, which was perpetuated throughout the interwar period. The demographic growth in depression has been closely linked to mining activities, continuing during the World War. The end of the war brought the installation of socialism to România. Socialists have not lost concern for the industry in the Jiu Valley, with activities continuing until 1989. After 1989 the industry went into regression, the closings of me succeeded.

The ethnic structure (fig. 2) of the population of the coal basin has suffered influence due to the intake of foreign settlers. The structure of 1850 is similar to that of 1857 , without significant changes, because the Habsburgs did not put so much emphasis on the importance of ethnicities. Between these years, the ethnic structure of Petroşani was composed of two

Tab. 1. Demographic evolution of Petroşani Depression

\begin{tabular}{|l|c|c|c|c|c|c|c|c|c|c|c|}
\hline $\begin{array}{c}\text { Administrative } \\
\text { unit }\end{array}$ & $\begin{array}{c}\text { Year } \\
1850\end{array}$ & $\begin{array}{c}\text { Year } \\
1857\end{array}$ & $\%$ & $\begin{array}{c}\text { Year } \\
1880\end{array}$ & $\%$ & $\begin{array}{c}\text { Year } \\
1900\end{array}$ & $\%$ & $\begin{array}{c}\text { Year } \\
1930\end{array}$ & $\%$ & $\begin{array}{c}\text { Year } \\
2011\end{array}$ & $\%$ \\
\hline Petroșani & 1,459 & 2,219 & +52 & 5,755 & +159 & 11,152 & +93 & 18,211 & +63 & 37,160 & +104 \\
\hline Petrila & 2,075 & 2,309 & +11 & 3,226 & +39 & 4,497 & +39 & 10,496 & +133 & 22,692 & +116 \\
\hline Vulcan & 817 & 1,636 & +100 & 2,030 & +24 & 3,016 & +48 & 14,053 & +365 & 24,160 & +71 \\
\hline Lupeni & 743 & 937 & +26 & 1,244 & +32 & 5,393 & +333 & 15,093 & +179 & 23,390 & +54 \\
\hline Aninoasa & 500 & 653 & +30 & 738 & +13 & 1,070 & +44 & 5,318 & +397 & 4,360 & -18 \\
\hline Uricani & 460 & 1,174 & +155 & 1,677 & +42 & 1,306 & -22 & 1,848 & +41 & 8,972 & +385 \\
\hline Bănița & 1,044 & 1,049 & +0.4 & 1,331 & +26 & 1,776 & +33 & 1,734 & -2 & 1,211 & -30 \\
\hline Total & 7,098 & 9,977 & +40 & 16,001 & +60 & 28,210 & +76 & 66,753 & +136 & 121,945 & +82 \\
\hline
\end{tabular}

Source: Data source and own calculation based on data based on data from: Rotariu et all., 1996; Rotariu et all., 1997a; Rotariu et all., 1997b; Rotariu et all., 1999; Rotariu et all., 2011, National Institute of Statistics. 
ethnic, Romanian and Gypsy. The Gypsy population was still present in Aninoasa (12 people), the Petrila (59 people) and the Vulcan (7 people). The most diversified ethnic structure was in the Vulcan where they cohabited four ethnicities: Romanians, Gypsies, Hungarians and Germans. In Lupeni, in addition to the Romanian population were ethnic Armenians, but only eight people, being the only ones in the entire depression during this period.

Since the census of 1880 , the ethnic structure has begun to diversify much more for all administrativeunits. The Armenian and Gypsy population disappeared completely, at the expense of other ethnicities that were brought from the Austro-Hungarian territories. A cause, the inexistence of ethnic Gypsies in hungarian censuses starting with the 1880 , can be placed on account of the fact that they have identified themselves as Hungarians, being incorporated into the herd of ethnic Hungarians. The Romanian population was majority in 1880 by $78 \%$, but ethnic Hungarians showed $10 \%$ and Germans in the $7 \%$ weight. Both Germans and Hungarians were heavily cantoned in Petroşani, their flocks reaching 926 and 1,081 people respectively. The second ethnicity after the Romanian one, in Petroşani was the Hungarian one, followed by the German one. Other fairly significant flocks were taken to the Petrila, 266 Hungarians and 161 Germans. Only in the two units their number was higher, in the other units being under 100 persons for each of the two nationalities. At Lupeni in 1880 there was no German, and 28 Rusyns and 2 Croats/Serbs were recorded at the time, being the only cases recorded in the entire depression of these two ethnicities. Small number, but not overlooked, was that of Slovaks, with only 66 people. The territorial distribution of Slovaks comprised three administrative-units: Petrila (29 persons), Petroşani (26) and Uricani (11). At Bănița, in 1880, the Romanian population was very clearly dominated, with the remaining ethnicities very low. The Slovak population had four people, and among Croats/Serbs only one.
The confessional structure of 1880 (fig. 3), positioned the Greek Catholics in the first place, with a weight of $42 \%$ (6,744 people). The Greek Catholic confession was followed by the Orthodox one, with a weight of $37 \%$ (5,957 people). The third religion is the Roman Catholic who holds a weight of $17 \%$ (2,669 people). These three confessions have the highest values, the following having much lower percentages. Only in the Petroşani and the Petrila, dominate the Orthodox, in the other units their number being very low. The number of orthodox in Petroşani was 3,094 people, and in the Petrila of 2,552. Something higher was at Bănița, but only 230 followers, however visible higher than in the rest of the units. The other units barely reach 54 to Lupeni, 20 to Vulcan, and at Aninoasa and Uricani the number of orthodox is very low, 3 and 4 respectively. Settlements significantly put their footprint on the confessional structure, with evidence being the majority confessional diversity at the level of the units. The Greek Catholic confession dominates five units, but the highest flock of the followers of this confession was at the Vulcan with 1,962 people. Vulcan, is followed not far from Uricani, with 1,611 Greek Catholics and Lupeni where there were 1,189 Greek Catholics. Their number decreases to Bănița where there were 984 Greek Catholics, and the lowest effective of only 677 in Aninoasa, but still remain a majority. Roman Catholics were massively positioned at Petroşani, and there were 1,888 people, where it is the second confession as effective after the Orthodox. The second highest value with 568 Roman Catholic followers is at the Petrila, following the trend at Petroşani, following the Bănița with 77. This confession is almost non-existent at Lupeni, in 1880 a single person was registered. The $17 \%$ share is supported by the high number recorded at Petroşani and Petrila. The spread of Evangelicals at the level of depression is unhomogeneous, so that their maximum number was 162 people in Petroşani. The second flock was at Bănița with a reduced value of 17 persons, and at Aninoasa the number was only 6 persons. There were

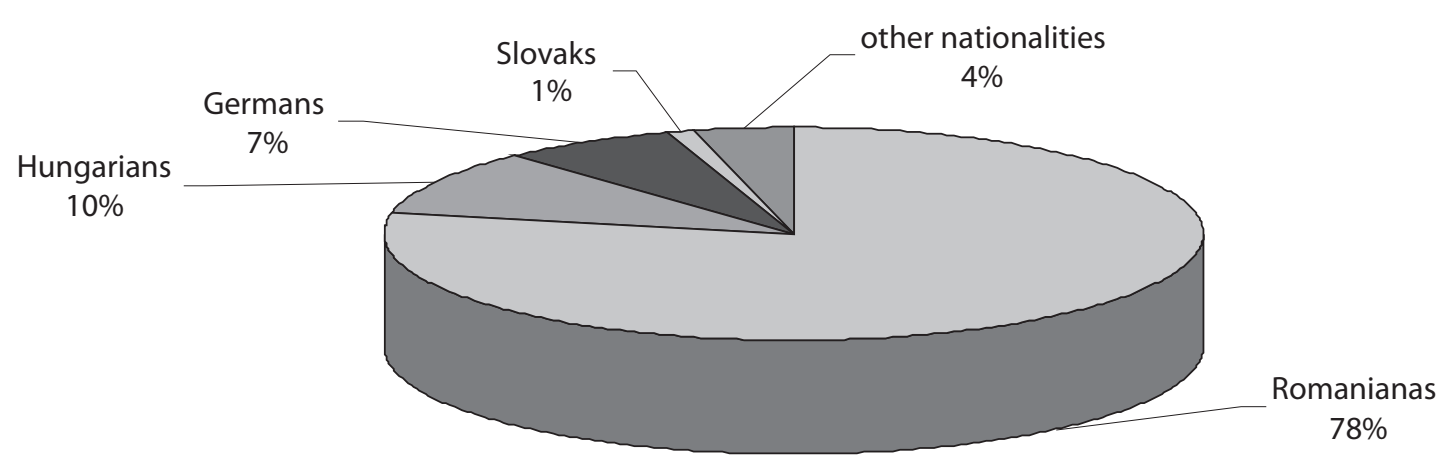

Fig. 2. The ethnic structure of Petroşani Depression in 1880

Source: own study based on Rotariu T-I. et al., 1997b. 


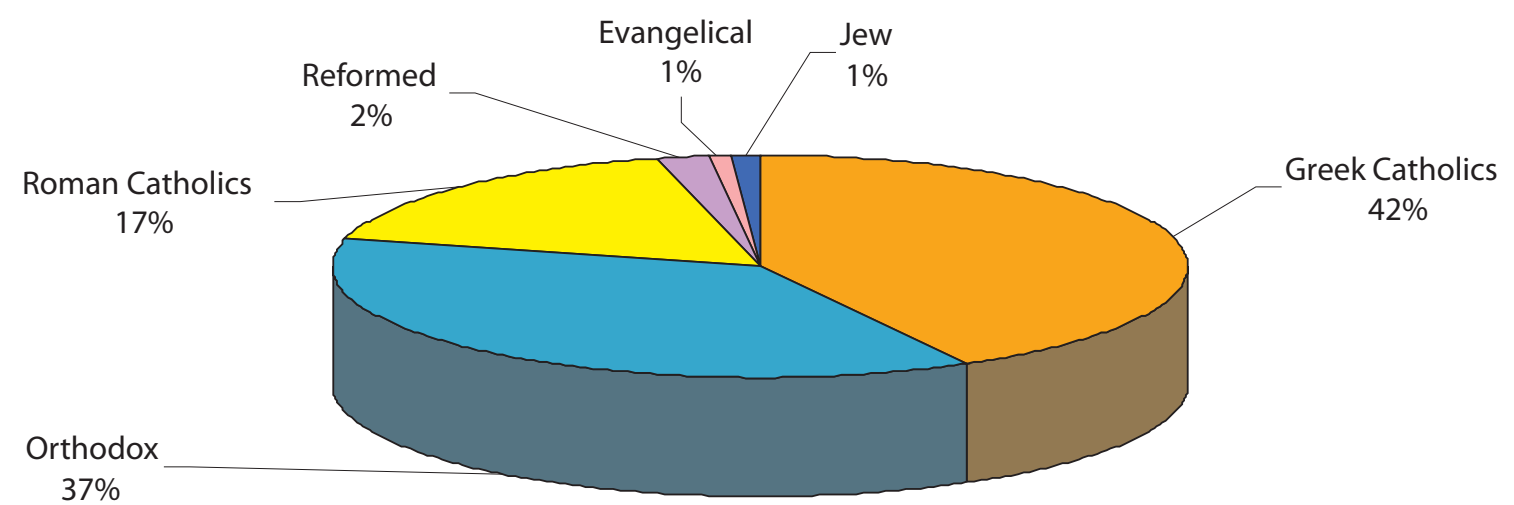

Fig. 3. Confessional structure of Petroşani Depression in 1880

Source: own study based on Rotariu T-I. et al., 1997b.

only two cases at Uricani. In Petrila and Vulcan, one case was recorded for each unit. The only unit where evangelicals were not registered was at Lupeni. The confessional structure of Lupeni was in 1880 the most homogeneous and very little diversified, with only three present, Orthodox, Greek Catholic, and Roman Catholic religions. The weight of less than $0 \%$ of Unitarians is explained by the fact that their flock was only 20 people in the entire depression. This confession was present in three administrative units. The maximum number was at Petroşani with 17 followers, at Aninoasa 2, and at Vulcan one person. Jew concentrated with preponderance at Petroşani where 150 of Jew lived, and the second most numerous Jew community was at the Petrila with only 16 people. The Jew community was very low as followers in the other units. At Vulcan and Bănița were five people, at Uricani four, and at Aninoasa one.

In the year 1900, the ethnic structure of the Petroşani Depression presented a great diversity (fig. 4). The end of the 19th century was marked by the presence of a multi-ethnic workforce in the coal industry in the Petroşani region. The workforce consisted of various tribes, populated for industrial purposes. The majority ethnicity was the Romanian one but flanked by many others, brought from parts of Moravia, Poland, Italy. Romanians owned $54 \%$ of the total ethnicity, meaning 15,472 people. Following them were Hungarians with a weight of $29 \%$, increasing compared to 1880 , numerical values reaching from 1,468 to 8,277 people. The evolution of Hungarians is one of the biggest gains of an ethnicity in the 20 years, with an increase of $463 \%$. Hungarians in 1900 held the majority in Petroşani, growing in only 20 years with $373 \%$. It is the only administrative unit in which the Hungarians and any other ethnicity possess the majority at the expense of Romanians. At Lupeni, in 1900 the number of Romanians is slightly higher than the Hungarians, the surplus of Romanians being only 32 people. The Hungarian population of Lupeni has grown extremely much in the 20 years. In 1880, there was only one person, and in 1900 the number reached 1,738 Hungarians, imposing as the most extreme ethnic growth in the second half of the 19th century in the Petroșani mining region. The second most important increase in the Hungarians was to Vulcan. The German population grew numerically with 1,241 people, and this growth was more than a doubling of German workers specializing in the mining industry. The largest number of the Germans was registered at Petroşani of 1,165 people, and their second largest flock decreases by almost half to the Petrila, where there were 604 Germans. In the temporal range of the two censuses of the population at the end of the 19th century, we can mention two administrative-units in which the evolution of the Germans was considerable. The most interesting case was at Lupeni where in 1880, there was no German citizen registered, following that in 1900 , their number would be 363 . The second situation in which the Germans increased, is at the Petrila, the increase being 275\%, from 161 to 604 by the Germans. At Aninoasa and Uricani their flocks were minima from depression, 21 Germans, respectively 22 and with a minimum change from 1880 . The flock of the Slovak population increased by $127 \%$ compared with 1880, from 70 people to 159 . In the year 1900 , the Slovak population was widespread in all administrative-units of the Petroşani Depression, compared to 1880 when ethnic Slovak was present in four units: Petroşani, Petrila, Uricani and Bănița. In Aninoasa, Lupeni and Vulcan, Slovaks were brought in after 1880, so the census of 1900 , in Lupeni, lived 23 Slovaks at Vulcan 9, and at Aninoasa 10. Ethnic Croats/Serbs have had an upward trend similar to the Slovaks. The remarkable difference is that in 1880 Croatia-Serbs were almost inexistent in depression, only two cases were recorded at the Petrila and one case at Bănița. Ethnic Croats/Serbs populated five of the six administrative units, missing perfection at 
Uricani. The maximum number was at Petroşani (17), followed by Aninoasa (10) and equal values for Lupeni and Vulcan (7). At the Petrila, the value recorded in 1880 was maintained. The two ethnics, Slovak and Croats/Serbs, had a share of less than $0 \%$ in 1900, but their importance was felt on the economic and commercial level. Ruthenians have evolved percentages, at a value similar to that of Croats/Serbs. The increase was exponential from 28 in 1880, to 538 in the year 1900 . The resemblance between the two ethnicities continues through their territorial distribution. The Ruthenian population just like the Croats/Serbs, existed only in the trill in the year 1880, to grow by the end of the age. In 1900, at the level of depression, two geographical positioning polluters are highlighted, which keep between them considerable values. A first pole, with the maximum number of Ruthenians in the depression was at Lupeni (457 people), and the second was at the Petrila with 63 people. In the other administrative-units, the herds were very low, only 14 to the Vulcan, to Petroşani three people and to Uricani one person. In the administrative area of Aninoasei, ethnic Ruthenians lacked perfection in 1900. Their share of the total ethnic structure was $2 \%$. For the year 1900, we cannot omit a few words about the $7 \%$ share of other ethnicities. The most numerous were poles that only at Lupeni were 1,035 people, but their distribution was also in other units. Polish miners and CzechMoravians were brought in as specialized workers in mining. The Petroşani mining was brought 362 by Italians, Poles and Czech-Moravians. A flock of 148 Czech-Moravians and Italians were also taken to the Petrila and Vulcan 75 by Poles and Czech-Moravians. 130 Italian and Polish workers reinforced mining activities at Aninoasa. From those mentioned, we can see that the workers in the preferences of AustriaHungary were the miners in the Czech-Moravian regions, which they brought and colonized in the vast coal basin that overlaps the Petroşani Depression.
In 1900, the confessional structure (fig. 5) in depression was much changed compared to the year 1880. The great diversity of workers brought to carry out mining activities has made significant contributions to the denominational modification of administrative-units at the end of the 19th century. All the confessions had increased followers, however, there are several cases where the number of followers in a given religion has risen much in just 20 years. Where people who identified themselves as Unitarians increased from 20 to 301 . The herd of the reformers increased 7 times from 242 to 1,876. As a result of the Reformations, there were Jew, numerical growth compared to 1880 being higher by 822 people. The Evangelical confession had an increase of $336 \%$, from 189 to 825 people. The number of Roman Catholics rose from 2,669 to 8,177 , which places them on the first position as a depresionar-level share. The increase was no less than $206 \%$. Roman Catholics had the most upward numerical increase of all depressed denominations. Among Orthodox and Greek Catholics, developments are identical and maintain equal weights, but somewhat lower than in 1880. The largest growth of the Orthodox was at Aninoasa (from 3 persons to 144) and Vulcan (from 20 people to 210). At the administrative unit level, the rises among the Roman Catholic community were considerable for each unit. The most visible case was at Lupeni where in 1880 there was a single Roman Catholic person in the 1900, the number increased to 2,300 . It is the largest growth in the entire half of the nineteenth century, among a depressed confession. At Vulcan, Roman Catholics increased from 39 people to 437 , and at Petroşani rose by $111 \%$ from 1,888 to 3,991 . These significant increases in Roman Catholic confession are due to the Hungarian population brought after 1880. In 1850, at Bănița there was no Orthodox, only Greek Catholics and two Reformed. 50 years later, the confessional structure was composed of a great diversity of religions. Only after 50 years, the Bănița lived 343 Orthodox, growing

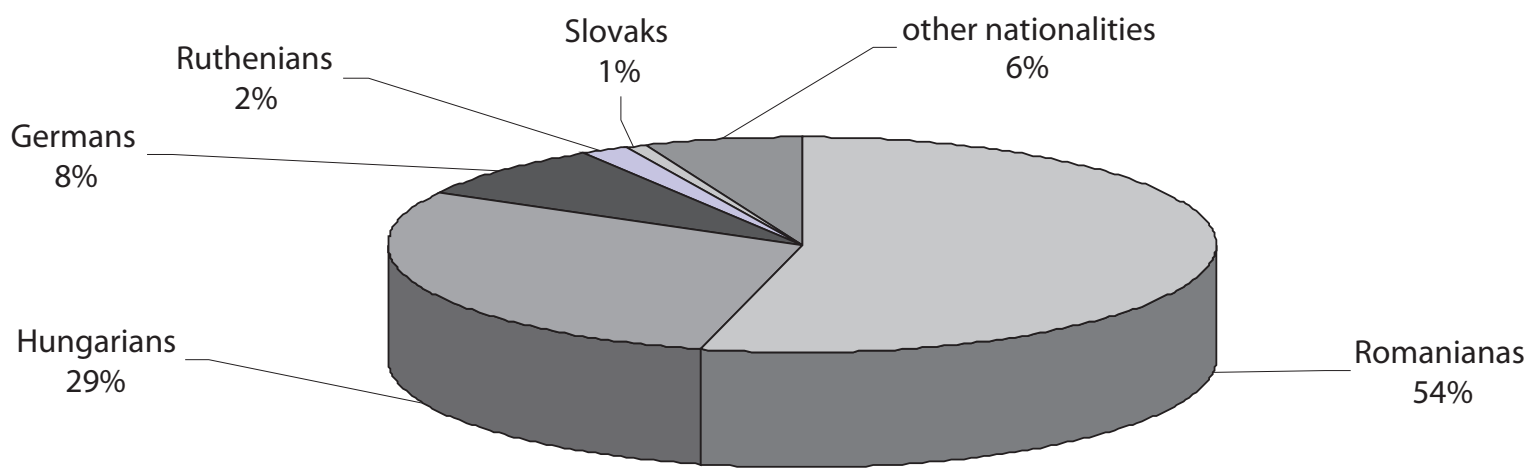

Fig. 4. Ethnic structure of Petroşani Depression in 1900

Source: own study based on Rotariu T-I. et al., 1999. 


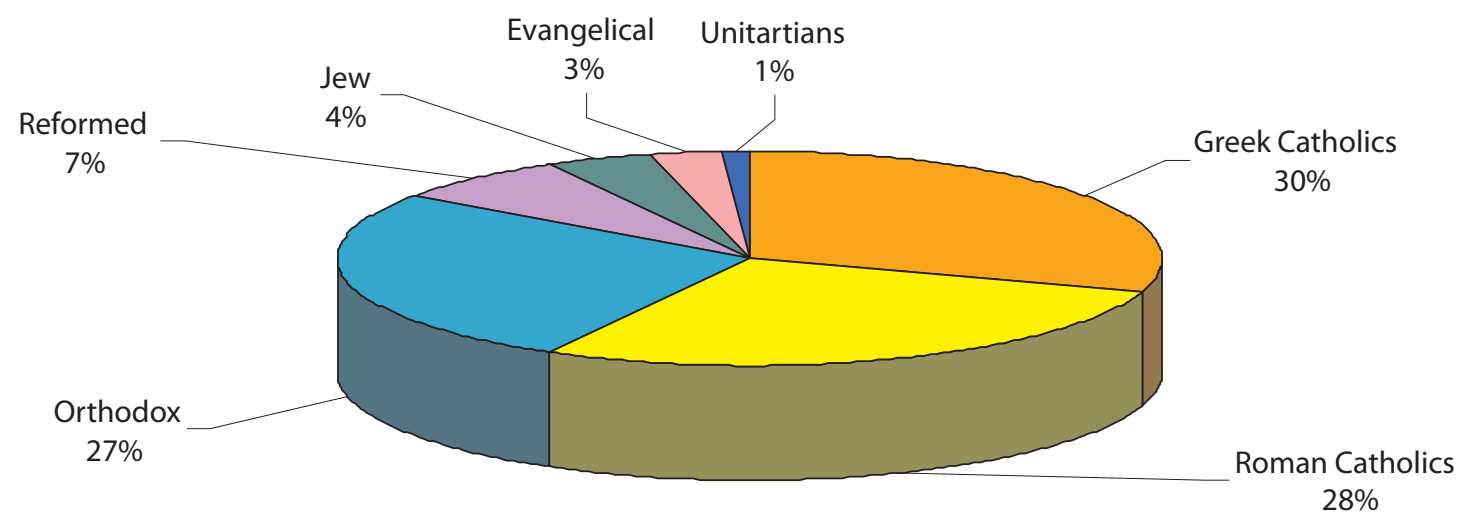

Fig. 5. Confessional structure of Petroşani Depression in 1900

Source: own study based on Rotariu T-I. et al., 1999.

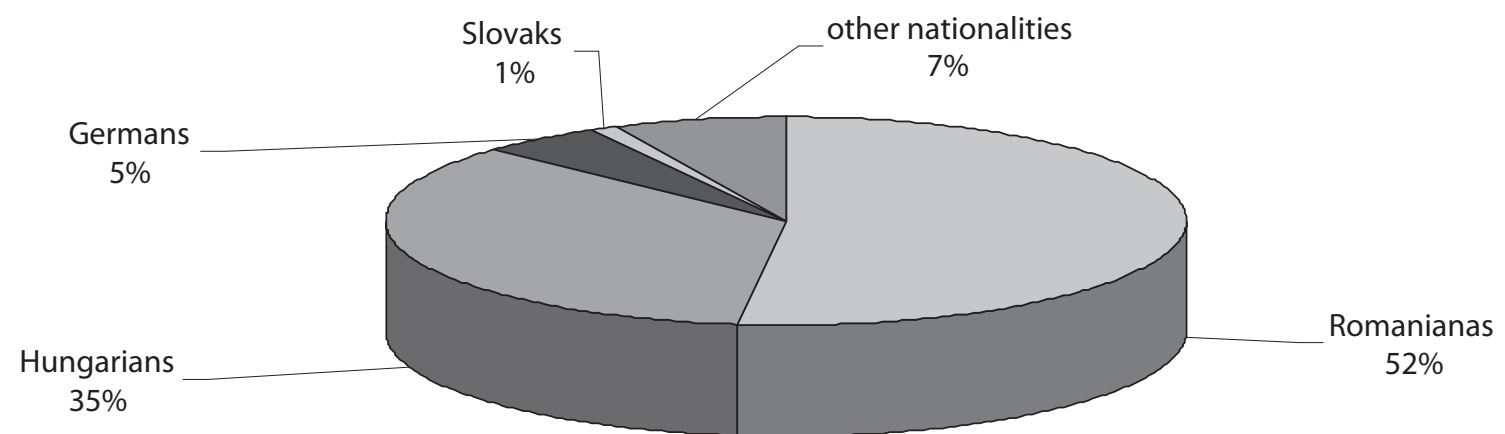

Fig. 6. Ethnic structure of Petroşani Depression in 1930

Source: own study based on Rotariu T-I. et al., 2011.

steadily starting with 1857 . The weakest confessions are the Unitarian with 12 people, Jew with eight people and Evangelize with five people.

In the ethnic structure of the year 1930 (fig. 6), the influences of the moment of the Great Union of 1918 were visible. The Romanian population was majority by $52 \%$, which marks the beginning of the supremacy of ethnic Romanians in depression. Compared to 1900 , the Romanian population increased by $57 \%$, thus doubling the number of Romanians was due to the passing of the Transylvanian space, the default of the depression with all mining activities under the control and administration of the Austro-Hungarian under Romanian leadership. The Hungarian population had a weight of $35 \%$, increasing by $65 \%$, but which would enter a downward meaning after 1930. The Hungarian population no longer dominates in any administrative unit, in two their number being decreasing compared to 1900. At Uricani was registered in 1930 a single Hungarian person, and the Hungarians fell by $187 \%$ (from 204 to 71 ) to Bănița. The remarkable industry in the Petroşani has led to the continuity of the Hungarians, the numerical evolution being increasing throughout the period of Dualistic Dominion and more than a decade after the surrender of the territory of the Romanian authorities. The German population had 5\% of the ethnic structure of 1930, with an increase of 35\%. Like the Hungarians, the Germans were stationed in the highest number at Petroşani. Numerically, decreased from 1900 to Petroşani, Vulcan, Uricani and Bănița, and in other units their number increased. These decreases were due to the labor migration from the four administrative-units, to the others where the need for specialised German workers was larger, due to the opening of new mining holdings. The Slovak population retained ascendancy as other ethnicities, growing from 1900 to 1930 in most units, except Băniței. In 1930, no person of Slovak ethnicity was registered at Bănița. The majority of ethnic Slovaks was established at the Petrila. The Croats/Serbs share was less than $1 \%$, but in numerical growth at Depresionar-level from 44 to 62 people. In the three units, the Vulcan, the Petrila, Lupeni their flock increased, and at Uricani there was no ethnic Croat/ Serb. The Ruthenian population decreased numerically at depresionar level in the 30 years, but most of the population was in Lupeni with 467 people. Ruthenians are missing with perfection at Aninoasa and Uricani, and the rest of the depression barely reaches 16 people ( 4 to Petroşani, 4 to Petrila, 8 to Vulcan). Other nationalities in the census are mostly ethnic Jews, registered 1,057 people at Petroşani, 64 to Aninoasa, 242 to Lupeni, 230 to Petrila, 5 to Uricani, 


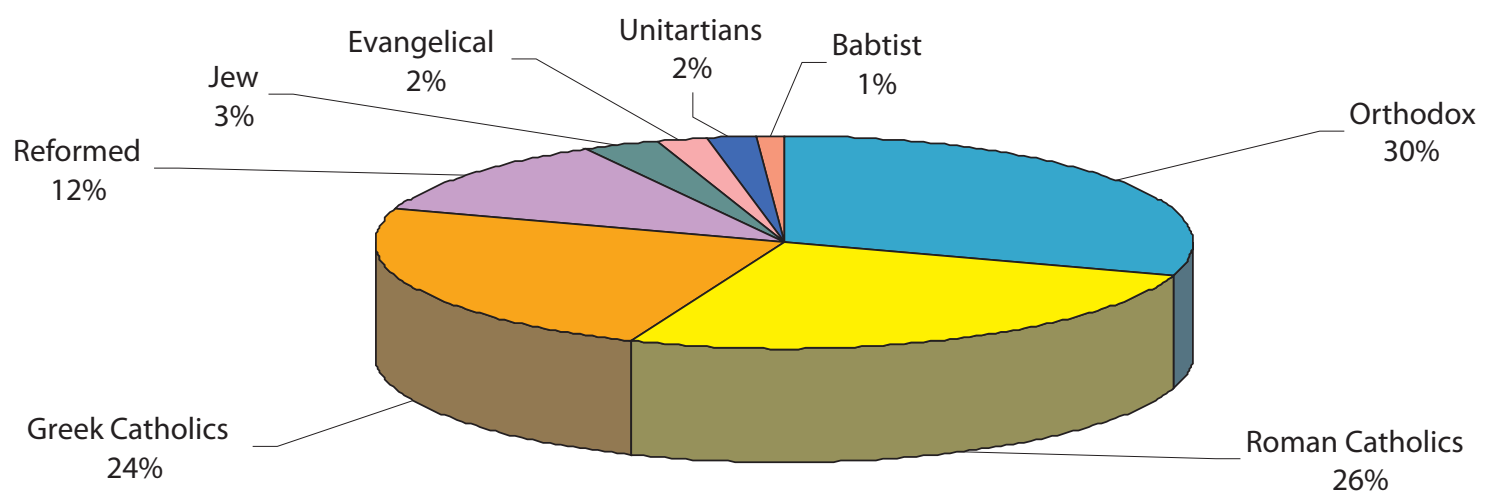

Fig. 7. Confessional structure of Petroşani Depression in 1930

Source: own study based on Rotariu T-I. et al., 2011.

416 to Vulcan and 7 to Bănița. The Jewish population was practically established in the whole depression, in larger or lower numerical herds, but their importance was increased in the conduct of commercial activities. It is probably the only ethnicity in the depression, which has not been colonised, its presence due to the trade achieved amid the magnitude of the mining industry. At the census of 1930, the presence of the Gypsy population was recorded in a flock of 330 people, missing only in Bănița. This ethnicity was only present in the censuses of 1850 and 1857, and in those of 1880, 1900 these ethnics no longer existed. The return to depression took place after the great Union, as a necessity for employment under precarious conditions. Aninoasa hosted the highest number of Gypsies, in 1930 there were 135 people. In the rest of the depression, their number decreased under 100 persons for each administrative unit. At Vulcan, it was the second Gypsy community with 62 people, followed Uricani with 47, the Petrila with 43, Petroşani with 38 and the smallest community of only 5 people at Lupeni.

At the census of 1930, the reins were taken over by the Romanian authorities, and the population census was conducted by high-value scientific researchers. It was a first census carried out by the Romanian authorities and the first to be carried out according to well-chosen criteria that would include as broad information as possible about the population. Under the confessional aspect, all religions recorded increases in the 30 years of the 20th century. Even under the impediment of World War I, the population of the coal basin thrived, and new religions appeared that until 1930 did not exist, or at least were not recorded in the previous censuses. The confessional structure of 1930 appears in fig. 7. The Baptist and Adventist Confession was the new religions that joined in addition to the depressed confessional painting. At the level of depression, the Greek Catholics were moved from the first position from 1900 to 1930 . The majority religion in 1930 was the Orthodox one, growing in the 30 years by $155 \%$, from 7,819 to 19,988 . The entry of the coal basin region, under romanian rule, was achieved by the growth of Orthodox and their dominance as a weight and flock. Roman Catholics have considerably increased the second confession, after the Orthodox one. Their number reached from 8,177 in 1900 to 17,078 in 1930 , registering the growth of $108 \%$. The Greek Catholics were barely the third confession in 1930, being the first time this religion surpassed so much, the increase being $81 \%$ compared to 1900 . However, Greek Catholics were the majority in Aninoasa, Lupeni, Uricani, Vulcan and Bănița. The Unitarian confession had the most significant growth in this early 20th century, increasing by $370 \%$, from 301 people to 1,415. The new two religions for 1930 were disproportionate as followers, thus the Baptist confession adhered to 503 people, and to the Adventist only 55 . At the local level, the largest growth among the orthodox was at the Vulcan, with a registered increase of $94 \%$. The most unhomogeneous, confessional structure was in Uricani, where Greek Catholics were clearly dominant with 1,780 people, and in their wake were Orthodox with only 39 people. In 1930, the Uricani were absent with perfection, Evangelicals and Unitarians, but 16 cases of Baptists were recorded instead. The Baptist confession, existed in six administrative units, and the largest number was at Lupeni by 281 people. In the rest of the units, the herds were under 100 persons. Adventists were present in five units, completely missing in Uricani and Bănița. The maxim Adventists was at Petroşani with 21 people, followed by the Vulcan by 14 . At the Petrila there were 10 and 5 in Aninoasa and Lupeni. With the passage of the depression under the Romanian command, the confessional structure changed from the second half of the 19th century. Some confessions grew in weights, others decreased what a confessional movement showed, representing a cause of the time of the Union in the year 1918. 
From 1930, passing through the period of World War II, the socialist period that period post-socialist the ethnic diversity in depression increased much compared to previous periods, especially those of colonization when they were brought into several waves the same populations. Since the second decade of the interwar period, most of the colonized populations have remigrated to their native places, following the entry of the territory under another leadership, namely due to restructuring in the industry. The Romanian population has established its domination categorically, a fact emerged from the data obtained from the census in the year 2011, Romanians holding $92 \%$, meaning numerically 104,502 people. The increase of the Romanian population from 1930 to 2011 was $66 \%$. All ethnicities have

Tab. 2. Ethnic structure of Petroşani Depression in 2011

\begin{tabular}{|c|c|c|c|c|c|c|c|c|}
\hline Ethnicities & Petroșani & Vulcan & Lupeni & Aninoasa & Petrila & Uricani & Bănița & Total \\
\hline Romanians & 30,926 & 21,250 & 19,365 & 3,711 & 19,969 & 8,097 & 1,184 & 104,502 \\
\hline Hungarians & 2,250 & 1,155 & 1,566 & 172 & 1,048 & 251 & 8 & 6,450 \\
\hline Gypsy & 597 & 321 & 771 & 298 & 165 & 173 & - & 2,325 \\
\hline Ukrainians & 4 & 4 & 4 & - & - & - & - & 12 \\
\hline Germans & 116 & 47 & 69 & 5 & 38 & 4 & - & 279 \\
\hline Turkish & - & - & 3 & - & - & - & - & 3 \\
\hline Serbs & - & 3 & - & - & - & - & - & 3 \\
\hline Slovaks & 7 & - & - & - & 3 & - & - & 10 \\
\hline Italians & 15 & 3 & 7 & 3 & - & - & - & 28 \\
\hline Jews & 6 & - & 3 & - & 4 & - & - & 13 \\
\hline Czechs & 3 & 4 & - & - & - & - & - & 7 \\
\hline Poles & 9 & 5 & 19 & - & - & - & - & 33 \\
\hline Chinese & 6 & - & - & - & - & - & - & 6 \\
\hline Other ethnicities & 36 & 5 & 14 & - & 4 & - & - & 59 \\
\hline
\end{tabular}

Date source: National Institute of Statistics.

Tab. 3. Confessional structure of Petroşani Depression in 2011

\begin{tabular}{|c|c|c|c|c|c|c|c|c|}
\hline Confessions & Petroșani & Vulcan & Lupeni & Aninoasa & Petrila & Uricani & Bănița & Total \\
\hline Orthodox & 28,585 & 19,145 & 17,717 & 3,592 & 17,244 & 7,363 & 1,144 & 94,790 \\
\hline Roman Catholic & 2,474 & 1,513 & 1,249 & 278 & 1,312 & 293 & 6 & 7,125 \\
\hline Reformed & 1,017 & 707 & 957 & 65 & 506 & 135 & 27 & 3,387 \\
\hline Pentecostal & 779 & 545 & 603 & 133 & 1,479 & 423 & - & 3,989 \\
\hline Greek Catholic & 207 & 142 & 338 & 23 & 67 & 42 & - & 819 \\
\hline Baptist & 174 & 112 & 320 & 19 & 83 & 55 & 4 & 767 \\
\hline Adventist & 71 & 32 & 68 & - & 31 & 17 & - & 219 \\
\hline Muslim & 13 & 4 & 6 & - & 5 & - & - & 28 \\
\hline Unitarian & 113 & 55 & 140 & 10 & 69 & 5 & - & 392 \\
\hline Jehovah & 260 & 287 & 189 & 52 & 281 & 92 & - & 1,161 \\
\hline Christian After Gospel & 41 & 34 & 34 & - & 43 & 36 & 11 & 199 \\
\hline Christian of Rite Old & 4 & 8 & 6 & - & - & - & - & 18 \\
\hline Evangelist Lutherana & 16 & 3 & - & - & - & - & - & 19 \\
\hline Orthodox Serbian & - & 3 & - & - & - & - & - & 3 \\
\hline Evangelical & 18 & 7 & 18 & 3 & 6 & - & - & 52 \\
\hline $\begin{array}{l}\text { Evangelical of confes- } \\
\text { sion Augustana }\end{array}$ & 12 & 4 & 17 & - & 5 & - & - & 38 \\
\hline Mozaica & 11 & - & 7 & - & - & - & - & 18 \\
\hline Atheists & 57 & 40 & 36 & 3 & 21 & 7 & - & 164 \\
\hline Other religions & 55 & 53 & 39 & 4 & 21 & 4 & - & 176 \\
\hline
\end{tabular}

Date source: National Institute of Statistics. 
fallen numerically to 2011, with the exception of the Romanian and Gypsy population (tab. 2). After Romanians, the second major increase was among the Gypsy community. The Gypsy community of depression increased by $86 \%$, in 2011 as the third largest ethnicity at the Depresionar-level. This ethnicity at the last census had no representative at Bănița, in the other units being present. Migrations affected Hungarian and German ethnicity. The Hungarian population fell by $72 \%$, from 23,611 in 1930 , to only 6,450 in 2011. At Petroşani was the largest population of Hungarians in the middle of the interwar period, but decreasing to 2011 by $200 \%$. Only at Uricani the Hungarian population prospered from 1930, when only one person was registered, with 250 people up to 2011. Their lowest flock was at Bănița with only eight people, decreasing by 63 people compared to 1930. The German population has migrated massively from depression to 2011 , decrease being with 2,953 people, from 3,232 to only 279 . From the figure below you can see the dominance of Romanians, namely the two ethnically distant, $6 \%$ Hungarian population and $2 \%$ Gypsy population. No fewer than 13 ethnicities were reviewed at the last census, of which ten had a weight of less than 1\%. Ethnicities such as Ukrainians, Serbs, Slovaks, Czechs, Poles, Jews continued to exist in depression throughout the 20th century and early 21 st century. Although, in smaller herds than in period of colonization, ethnicities have retained their character of continuity.

The confessional structure has diversified very much, with 17 religions registered in 2011 (tab. 3). Many of the new religions registered in 2011, appeared after the year 1990. Thus we can talk about confessional continuity only to the religions that existed since the second half of the 19th century. Of the 17 only seven have weights of 1 or more $1 \%$, which shows that there are many confessions that are less represented, as the Orthodox religion dominates with $84 \%$ (94,790 people). Roman Catholics positioned from the Orthodox, but at very high distance by only $6 \%$ (7,125 people). Two new religions emerged after 1990 in the depresionar space, came to be among the top five most represented confessions. Pentecostals, ranks in the third position as the share of $4 \%$ respectively 3,989 people and the confession of Jehovah's witnesses with 1,161 people and $1 \%$. Following the Pentecostal are Reformed with $3 \%$ and 3,387 people. Compared to 1930, religions that were continuously ascending, such as the Greek Catholic, Reformed, Roman Catholic arrived in 2011 to hold very low weights and numbers. These decreases were due to the migrations of the Hungarian, German-depressed population. Among the great religions, the Greek Catholic confession fell from 1930, with 15,018 followers, from 15,837 people to just 819 . The Roman Catholic religion was the second in 1930, with 17,078 followers, and in 2011 their number reached 7,125 , a decrease by $139 \%$. However, even though the numerical numbers of these great denominations decreased due to demographic migrations, they kept their character of continuity from the second half of the 19th century, continuing throughout the 20th century to the beginning of the 21 century.

\section{Conclusions}

The Petroşani Depression was extensively subjected to colonization phenomena especially during the Austro-Hungarian domination period. In order to exploit the coal resources as highly as possible, skilled workers were brought in from various origins. The infusion of workers led to ethnic and confessional diversification in the space of depression. All ethnicities and confessions existing in the Petroşani Depression from the second half of the 19th century retained continuity in the 20th century and until the first part of the 21 st century. Even though the numerical data of some ethnicities and confessions fell after the Great Union of 1918, they continued to exist in lower herds. The ethnic and confessional cyclicality in the Petroşani Depression was closely linked to the cycles of demographic colonization, politicalhistorical events that destabilised the ethnic and confessional depression. The numerical numbers of the two demographic structures have undergone continuous changes. The cyclicality of herds has been influenced by the historical and political factor. This factor would change with the great Union of 1918, when the Romanian authorities took control of Transylvania and the Petroşani Depression. After this moment, among the two demographic structures there were significant changes. The ethnic structure has changed, due to the departure of ethnics, and this has led to a change in the confessional structure. Basically, the confessional structure was directly influenced by the changes in the ethnic structure. To note, it is that in addition to existing ethnicities and confessions, since the second half of the 19th century, new ethnicities and confessions have been registered in 2011.

\section{References}

Bodocan V., 2001, Etnie, confesiune si comportament electoral in Transilvania: studiu geografic (Eng. Ethnicity, confes- 
sion and electoral behaviour in Transylvania: geographic study), Editura Presa Universitară Clujeană, Cluj-Napoca.

Crețan R., 1999, Etnie, confesiune și comportament electoral în Banat: studiu geografic (sfârșitul sec. al XIX-lea și sec. al XXlea) (Eng. Ethnicity, confession and electoral behaviour in Banat: geographical study (late 19th and 20th century), Editura Universitatea de Vest, Timișoara.

Fearon J., David L., 2003, Ethnicity, Insurgency, and Civil War, American Political Science Review, 97(1), 75-90. doi: 10.1017/S0003055403000534

Horowitz D., 1985, Ethnic Groups in Conflict, University of California Press, Berkeley.

Ilieş A., 1998, Etnie, confesiune și comportament electoral în Crișana și Maramureș: (sfârșitul sec. XIX și sec. XX): studiu geografic (Eng. Ethnicity, confession and electoral behaviour in the Crișana and Maramureş: (late 19th and 20th century): geographic study), Editura Dacia, Cluj-Napoca.

Levinson D., 1998, Ethnic Groups Worldwide, Oryx Press, Phoenix.

National Institute of Statistics, http://statistici.insse.ro/shop/ (accessed 05 September 2018).

Reilly B., 2000/2001, Democracy, Ethnic Fragmentation, and Internal Conflict, International Security, 25(3), 162-185.

Rotariu T-I., Culic I., Karnoouh C., Mezei E., Pah I., Poledna R., Semeniuc M., 1997a, Recensământul din 1857, Transilvania (Eng. Census of 1857, Transylvania), Editura Staff, ClujNapoca.

Rotariu T-I., Semeniuc M., Mezei E., 1996, Recensământul din 1850, Transilvania (Eng. Census of 1850, Transylvania), Editura Staff, Cluj-Napoca.

Rotariu T-I., Semeniuc M., Mezei E., 1999, Recensământul din 1900, Transilvania (Eng. Census of 1900, Transylvania), Editura Staff, Cluj-Napoca.

Rotariu T-I., Semeniuc M., Mezei E., Moga M., Şomfelean L., Poledna R., 2011, Recensământul din 1930, Transilvania (Eng. Census of 1930, Transylvania), Editura Presa Universitară Clujeană, Cluj-Napoca.

Rotariu T-I.. Mureşan C., Semeniuc M., 1997b, Recensământul din 1880, Transilvania (Eng. Census of 1880, Transylvania), Editura Staff, Cluj-Napoca.

Rothchild D., 1978, Ethnicity and Purposive De-politicisization: The Public Policies of Two Ghanaian Military Regimes, a paper presented at the 21st Annual meeting of the African Studies Association, Philadelphia.

Scarritt J., Shaheen M., 1999, The Specification of Ethnic Cleavages and Ethnopolitical Groups for the Analysis of Democratic Competition in Africa, Nationalism and Ethnic Politics, 5(1), 82-117. doi: 10.1080/13537119908428555

Şişeştean G., 2002, Etnie, confesiune și căsătorie în nord-vestul Transilvaniei (Eng. Ethnicity, confession and marriage in northwestern Transylvania), Editura Caiete Silvane, Zalău.

Tofan G-B., 2014, The ethnic and confessional structure of Mureș County in 2011, Analele Universității din Oradea: Seria Geografie, 24(1), 14-22.

Tofan G-B., 2015, Etnie, confesiune şi comportament electoral în județele Harghita, Covasna şi Mureş: studiu geografic (2008-2014) (Eng. Ethnicity, confession and electoral behaviour in Harghita, Covasna and Mureş counties: geographical Study (2008-2014), Editura Casa Cărții de Ştiință, Cluj-Napoca.

Tofan G-B., Niță A., Nimară C., 2014, The Confessional structure of Harghita, Covasna and Mureș Counties, in 2011, Analele Universităţii din Oradea: Seria Geografie, 24(2), 166-179.

Vanhanen T., 1999, Domestic ethnic conflict and ethnic nepotism: A comparative analysis, Journal of Peace Research, 36(1), 55-73. doi: 10.1177/0022343399036001004 